\title{
S-Phase Accumulation of Candida albicans by Anticandidal Effect of Amentoflavone Isolated from Selaginella tamariscina
}

\author{
Hyun Jun JunG, ${ }^{a}$ Keunnam PArK, ${ }^{a}$ In-Seon LeE, ${ }^{b}$ Hyun Soo KIm, ${ }^{b}$ Soo-Hwan Yeo, ${ }^{c}$ \\ Eun-Rhan Woo, ${ }^{*}, d$ and Dong Gun LeE*,a \\ ${ }^{a}$ Department of Microbiology \& Immunology, School of Life Sciences and Biotechnology, College of Natural Sciences, \\ Kyungpook National University; 1370 Sankyunk-dong, Buk-gu, Daegu 702-701, Korea: ${ }^{b}$ The Center for Traditional \\ Microorganism Resources (TMR), Keimyung University; Daegu 704-701, Korea: ${ }^{c}$ Rural Resources Development Institute, \\ National Institute of Agricultural Science and Technology, Rural Development Administration; Suwon 411-853, Korea: \\ ${ }^{d}$ College of Pharmacy, Chosun University; 375 Seosuk-Dong, Dong-gu, Gwangju 501-759, Korea. \\ Received January 31, 2007; accepted June 26, 2007
}

\begin{abstract}
Amentoflavone, which is a biflavone derived from various plants, has been known to possess various biological activities including anti-tumor and anti-inflammatory activity. In the previous study, we reported antifungal effect of amentoflavone isolated from an ethyl acetate extract of Selaginella tamariscina on human pathogenic fungi. Amentoflavone significantly inhibited the growth of fungal cells without hemolysis of human erythrocytes. In the present study, we investigated antifungal acting mode of amentoflavone in human pathogenic yeast $C a n-$ dida albicans. Anticandidal activity was exerted in an energy-independent manner presented by an antifungal assay in the presence of $\mathrm{NaN}_{3}$, which is ATP-depleting agent as a metabolic inhibitor. To investigate the effects of amentoflavone on cellular physiology in $C$. albicans, we performed cell cycle analysis, and the analysis showed that amentoflavone significantly arrested cell cycles during the S-phase. These results demonstrated that amentoflavone has potent anticandidal activity with significant physiological changes inducing S-phase arrest in intracellular environment. Therefore, amentoflavone may be applied to a lead compound for the development of therapeutic agents, which can treat candidiasis resulted from candidal infections.
\end{abstract}

Key words biflavone; amentoflavone; anticandidal activity; C. albicans; cell cycle arrest

Flavonoids are ubiquitous polyphenolic compounds in vascular plants. They are important constituents of human dietary sources, such as fruits and vegetables, and they are also important for the growth, development and defense of plants. ${ }^{1)}$ There are numerous flavonoids such as apigenin, genistein, narigenin, malvidin chloride and amentoflavone, and flavonoids exhibit various favorable biological and pharmacological effects. ${ }^{1-3)}$ Amentoflavone belongs to a flavonoid class that is found in a number of plants including Ginkgo biloba, Hypericum perforatum, Ouratea multiflora and related Selaginella species. ${ }^{4-7)}$ Selaginella tamarisina, Korean name Keoun-Back which belongs to Selaginellaceae, has been traditionally used in treating blood in excrement, hematuria, prolapse of the anus and stanching. ${ }^{8}$ It is proved that Selaginella species contain a large number of active compounds, the most important of which are biflavonoids. ${ }^{9)}$

Amentoflavone, which is one kind of biflavone, has various pharmacological effects. It can act as an anti-inflammatory, ${ }^{3,10-13)}$ anti-urcerogenic, ${ }^{13)}$ anti-depressant, ${ }^{3)}$ anti-oxidant, ${ }^{14)}$ analgesic ${ }^{15)}$ and it has cytotoxic activity. ${ }^{16,17)}$ Besides such biological activity, there have also been reports regarding its biological effects toward microorganisms. Studies have shown that amentoflavone has antiviral activity against influenza, herpes, and respiratory syncytial virus (RSV) ${ }^{18,19)}$ and antifungal activity with the main focus being on phytopathogens, which coincides with the inhibition of phytopathogen infections. Amentoflavone was isolated from three different plants including Cupressocyparis leylandii, Taxus baccata, and Ginkgo biloba, and it exhibited antifungal activity against phytopathogenic fungi Alternaria alternate, Cladosporium oxysporum, Fusarium culmorum, and Fusarium avenaceum. ${ }^{20,21)}$

Although some studies have revealed the antimicrobial ef- fects of amentoflavone, there is a paucity of research regarding antifungal effects on human pathogenic fungi except our previous study. ${ }^{22)}$ In the previous study, we found antifungal activity of amentoflavone against human pathogenic fungi, but the effect induced by this compound in intracellular condition of $C$. albicans remains unknown. Here, to substantiate the action of amentoflavone in C. albicans, we investigated the correlation between the activity of amentoflavone and physiological changes in the human pathogenic yeast $C$. albicans.

\section{MATERIALS AND METHODS}

Plant Material, Fungal Strains, and Growth Condition A Selaginella tamariscina SpRING plant (Selaginellaceae) was purchased from a local herb drug market in Gwangju, Korea, and was authenticated by the Department of Pharmacognosy, Chosun University. Candida albicans (TIMM 1768) was obtained from the Center for Academic Societies, Osaka, Japan. C. albicans cells were cultured in YPD ( $2 \%$ Dextrose, $1 \%$ Peptone, $0.5 \%$ Yeast extract) medium at $28^{\circ} \mathrm{C}$ overnight, and the innoculum size to test antifungal activity was $10^{3}$ $10^{4}$ cells per milliliter.

The Isolation and Identification of Amentoflavone The whole plant of Selaginella tamariscina $(600 \mathrm{~g})$ was extracted with $\mathrm{MeOH}$ at room temperature yielding $50.54 \mathrm{~g}$ of residue. The methanol extract was re-suspended in water and partitioned sequentially with dichloromethane, ethyl acetate, and $n$-butanol. The EtOAc fraction $(3.0 \mathrm{~g})$ was placed on a silica gel $(300 \mathrm{~g}, 4.8 \times 45 \mathrm{~cm})$ column and eluted using a $\mathrm{CHCl}_{3}-\mathrm{MeOH}-\mathrm{H}_{2} \mathrm{O} \quad(12: 1: 0.1 \rightarrow \rightarrow 8: 1: 0.1 \rightarrow 5: 1: 0.1 \rightarrow$ $2: 1: 0.1 \rightarrow 1: 1: 0.1 \rightarrow \mathrm{MeOH}$ only) gradient system. Based on their TLC patterns, fractions were combined to yield sub- 
fractions, which were designated as E1-10. Subfraction E7 $(296.33 \mathrm{mg}$ ) was finally purified by repeated column chromatography over a silica gel, RP-18, and Sephadex LH 20, which yielded amentoflavone $(82.23 \mathrm{mg})$. UV, IR, ${ }^{1} \mathrm{H}-$, and ${ }^{13} \mathrm{C}$-NMR data, for amentoflavone, were identical to those reported in literature. ${ }^{17,23,24)}$

The Effects of Sodium Azide $\left(\mathrm{NaN}_{3}\right)$ on Antifungal Activity To investigate the effects of $\mathrm{NaN}_{3}$ on the antifungal activity of amentoflavone in C. albicans, its activity was determined either in the absence or presence of $0.002 \% \mathrm{NaN}_{3}$. The subcultured $C$. albicans cells were cultured at a half of MIC in the absence or presence of $0.002 \% \mathrm{NaN}_{3}$. After incubation for $12 \mathrm{~h}$ at $28^{\circ} \mathrm{C}$, the suspensions were plated on YPD agar plates, and the CFUs were counted.

Cell Cycle Analysis Log-phased C. albicans cells $\left(1 \times 10^{9}\right.$ per $\left.\mathrm{ml}\right)$ were cultured in a $1 \mathrm{ml}$ fresh YPD containing $100 \mu \mathrm{g}$ of amentoflavone. After incubation for $6 \mathrm{~h}$, the cells were washed with a PBS and fixed with $70 \%$ ethanol (in PBS) at $4{ }^{\circ} \mathrm{C}$ overnight. Two-hundred microgram of RNase A was added to the fixed cells, and the mixture was allowed to react for $2 \mathrm{~h}$ at $37^{\circ} \mathrm{C}$. After the reaction, $50 \mu \mathrm{g}$ of propidium iodide (PI) were added, and the samples were incubated for $4 \mathrm{~h}$ at $4{ }^{\circ} \mathrm{C}$ in the dark. DNA content was determined by the FACScalibur Flow Cytometer (Becton Dickinson, San Jose, CA, U.S.A.). Some 15000 cells were scored.

\section{RESULTS}

Isolation and Purification of Amentoflavone Repeated column chromatography of the methanol extract of $S$. tamariscina yielded E7 (Fig. 1). E7 was identified as amentoflavone by means of spectral data and a comparison was conducted with published data. ${ }^{17,23,25)}$

The Effects of Sodium Azide $\left(\mathrm{NaN}_{3}\right)$ on the Anticandidal Activity of Amentoflavone In the previous study, amentoflavone showed significant antifungal activity at low concentration conditions, which was similar to the level of amphotericin B. Fungal cell viability in the presence of $5 \mu \mathrm{g} / \mathrm{ml}$ of amentoflavone was significantly decreased during from 2 to $4 \mathrm{~h}$, and the decreasing curve was similar to one by $2.5 \mu \mathrm{g} / \mathrm{ml}$ of amphotericin B. After $8 \mathrm{~h}$ by incubation with these compounds, cell viability was maintained low cell viability which was less than $10 \%$ of control. Cellular energy synthesis is important for the entry of essential molecules regarding cell growth and proliferation. The metabolic inhibitor for ATP depletion can inhibit the imported system from an extracellular environment into a cell and induce membrane depolarization by disrupting proton gradient. ${ }^{26,27)}$ We investigated the effect of $\mathrm{NaN}_{3}$ as a metabolic inhibitor on C. albicans cells incubated with amentoflavone, for $12 \mathrm{~h}$ at $28^{\circ} \mathrm{C}$ in the absence or presence of $0.002 \% \mathrm{NaN}_{3}$, a metabolic inhibitor. One-half MICs of amentoflavone, in the absence and presence of $\mathrm{NaN}_{3}$, displayed about $44.5 \%$ and $40.5 \%$ cell survival, respectively (Fig. 2 ). These percentages represent average of measurements conducted in triplicate, and each independent assay did not display any significant differences according to $\mathrm{NaN}_{3}$.

The Effects of Amentoflavone on the Cell Cycle To probe further how amentoflavone inhibited the progressive change of individual cells within a physiological state, cell cycle analysis was performed. The cell cycle analysis is

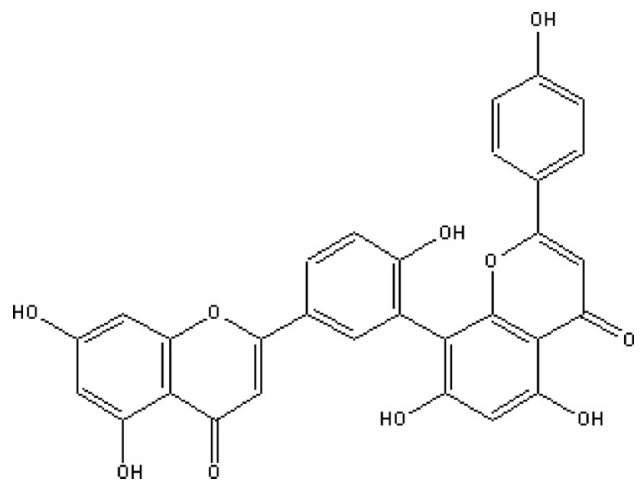

Fig. 1. Chemical Structure of Amentoflavone

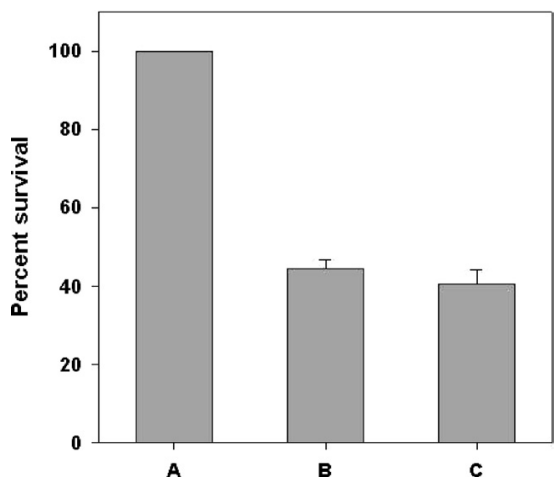

Fig. 2. The Effect of Sodium Azide $\left(\mathrm{NaN}_{3}\right)$ on Amentoflavone

C. albicans were treated with $2.5 \mu \mathrm{g}$ of amentoflavone. (A) Control, (B) amentoflavone, (C) amentoflavone and $\mathrm{NaN}_{3}$-treated cells.

based on DNA content that stained propidium iodide (PI), which is a membrane impermeant nucleic acid intercalator, ${ }^{28,29)}$ as measured by FACS analysis. The results revealed a reduction in the cell populations by about $10 \%$ (from 26.69 to $13.50 \%$ ) compared with the non-treated cells in the $\mathrm{G} 2 / \mathrm{M}$ phase of the cell division cycle. On the other hands, the Sphase population significantly increased from 12.37 to $36.47 \%$ of the total cell population (Fig. 3). It reflected that amentoflavone induced cell cycle arrest within the S-phase in yeast cells by its biological activity in the intracellular condition.

\section{DISCUSSION}

C. albicans colonizes the mucosal surfaces of the respiratory tract and the vaginal cavity and is able to cause serious infection depending on the defects of the host immune system. Nosocomial bloodstream infections due to the Candida species, including $C$. albicans, are linked with a mortality rate of over $40 \%$ in the US, and it is the fourth leading cause of bloodstream infections inducing significant morbidity and mortality. ${ }^{30)}$

Previous reports have revealed that the various biological activity of amentoflavone in mammalian cells and animal models, and has suppressed virus and phytopathogenic fungi, along with in vitro antimicrobial activity. In the previous study, we isolated amentoflavone from the herbal plant $S e$ laginella tamariscina, and elucidated antifungal effects concerning phytochemical antimicrobials. Owing to the potent antifungal effects on these yeast, as well as amphotericin B, 
A

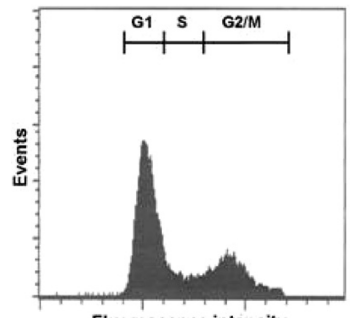

B

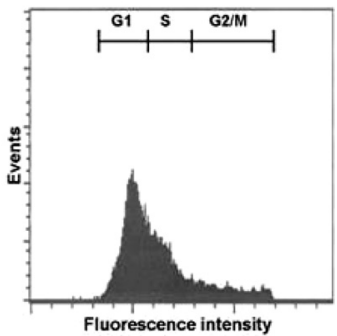

C

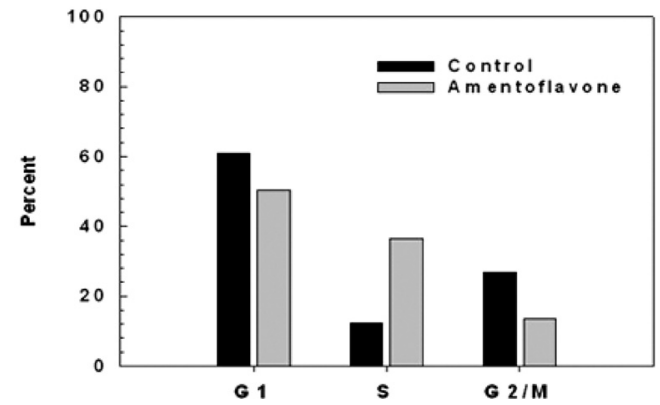

Fig. 3. Effects of Amentoflavone on the Cell Cycle

Amentoflavone treatment of $C$. albicans cells results in the accumulation of cells in the S-phase and a decrease of the percentage of cells in G1 and G2/M. For cell cycle analysis, propidium iodide-stained nuclei were analyzed by FACScalibur. Histogram of (A) control, (B) amentoflavone-treated cells, and (C) percent of the cells in the cell cycle progress.

we reported that the supplementary biological activity of amentoflavone had potential as an antifungal drug in treating candidal infections. ${ }^{22)}$ Our result contributed fungicidal activity that may lead to the cell death of $C$. albicans, but not fungistatic activity.

In this paper, we have analyzed anticandidal activity in the absence or presence in $\mathrm{NaN}_{3} \cdot \mathrm{NaN}_{3}$, as an inhibitor of oxidative phosphorylation, induces the impairment of mitochondrial energy synthesis, and it interferes with particular agents that require energy consumption. ${ }^{26,31,32)} \mathrm{NaN}_{3}$ also inhibits cellular importing systems by ATP depletion. Considering this point, the entry of amentoflavone into the fungal cells is not mediated by cellular function which requires cellular energy consumption such as ATP-dependent transporter (Fig. 2).

Various plant-derived polyphenolic compounds have been reported as having oxidative DNA-cleavage in the presence of transition metal ions; amentoflavone is capable of oxidative DNA cleavage in the presence of copper ions in vitro. ${ }^{33)}$ Moreover, it has been reported that flavonoids, including amentoflavone, inhibit DNA synthesis by the inhibition of reverse transcriptases in vitro. ${ }^{34)}$ Cell cycle analysis elucidated the S-phase arrest of the cell cycle by amentoflavone in $C$. albicans cells (Fig. 3). Although there are not direct evidences for a close relation between anticandidal activity of amentoflavone and cell-cycle arrest by the disturbance of certain metabolic process, these results suggested that this compound can affect the cell cycle progress of candida cells. Therefore, our study makes it possible our anticipation to induce the physiological changes of $C$. albicans cells by amentoflavone leading to the cell death.

In conclusion, amentoflavone from Selaginella tamariscina showed potent anticandidal activity in energy-independ- ent manner and was able to induce significant physiological changes related to cell cycle progress. Therefore, our study revealed that amentoflavone has excellent potential as a therapeutic agent in treating candidiasis by candida infections.

Acknowledgement This work was supported by Ministry of Commerce, Industry Energy (MOCIE) through the Center for Traditional Microorganism Resources (TMR) at Keimyung University.

\section{REFERENCES}

1) Carlo G. D., Masclo M., Izzo A. A., Capasso F., Life Sci., 65, 337353 (1999).

2) Lee H. S., Oh W. K., Kim B. Y., Ahn S. C., Kang D. O., Shin D. I., Kim J., Mheen T. I., Ahn J. S., Planta Med., 62, 293-296 (1996).

3) Baureithel K. H., Buter K. B., Engesser A., Burkard W., Schaffner W., Phym. Acta Helv., 72, 153-157 (1997).

4) Lobstein-Guth A., Briancon-Scheid F., Victoire C., Haag-Berrurier M. Anton R., Planta Med., 54, 555-556 (1998).

5) Patocka J., J. Appl. Biomed., 1, 61-73 (2003).

6) Felicio J. D., Rossi M. H., Park H. R., Goncalez E., Braggio M. M., David J. M., Cordeiro I., Fitoterapia, 72, 453-455 (2001).

7) Lee S. W., Chen Z. T., Chen M. T., Zhong Yao Zazhi, 44, 537-541 (1992).

8) Kim J. W., Shin D. I., Kor. J. Pharmacos., 22, 207-210 (1991).

9) Okigawa M., Hwa C. W., Kawano N., Rahman W., Phytochemistry, 10, 3286-3287 (1971).

10) Kim H. K., Son K. H., Chang H. W., Kang S. S., Kim H. P., Arch. Pharm. Res., 21, 406-410 (1998).

11) Gil B., Sanz M. J., Terencio M. C., Gunasegaran R., Paya M., Alcaraz M. J., Biochem. Pharmacol., 53, 733-740 (1997).

12) Gambhir S. S., Geol R. K., Das Gupta G., Indian J. Med. Res., 85, 689-693 (1978).

13) Kim H. P., Mani I., Iversen L., Ziboh V. A., Prostaglandins, Leukot. Essent. Fatty Acids, 58, 17-24 (1998).

14) Cholbi M. R., Paya M., Alcaraz M. J., Experientia, 47, 195-199 (1991).

15) Da Silva K. L., Dos Santos A. R., Mattos P. E., Yunes R. A., DelleMonache F., Cechinel-Filho V., Therapie, 56, 431-434 (2001).

16) Lin L. C., Kuo U. C., Chou C. J., J. Nat. Prod., 63, 627-630 (2000).

17) Silva G. L., Chai H., Gupta M. P., Farnsworth N. R., Cordell G. A., Pezzuto J. M., Beecher C. W., Kinghorn A. D., Phytochemistry, 40, 129-134 (1995).

18) Lin Y. M., Flavin M. T., Schure R., Chen F. C., Sidwell R., Barnard D. L., Huffman J. H., Kern E. R., Planta Med., 65, 120-125 (1999).

19) Ma S. C., But P. P., Ooi V. E., He Y. H., Lee S. H., Lee S. F., Lin R., Biol. Pharm. Bull., 24, 311-312 (2001).

20) Krauze-Baranowska M., Cisowski W., Wiwart M., Madziar B., Planta Med., 65, 572-573 (1999).

21) Krauze-Baranowska M., Wiwart M., Z. Naturforsch., 58c, 65-69 (2003).

22) Jung H. J., Sung W. S., Yeo S., Kim H. S., Lee I., Woo E., Lee D. G., Arch. Pharm. Res., 29, 746-751 (2006).

23) Markham K. R., Sheppard C., Geiger H., Phytochemistry, 26, 33353337 (1987).

24) Woo E. R., Pokharel Y. R., Yang J. W., Lee S. Y., Kang K. W., Biol. Pharm. Bull., 29, 976-980 (2006).

25) Woo E. R., Lee J. Y., Cho I. J., Kim S. G., Kang K. W., Pharmacol. Res., 51, 539-546 (2005).

26) Gyurko C., Lendenmann U., Helmerhorst E. J., Troxler R. F., Ooppenheim F. G., Antonie van leeuwenhoek, 79, 297-309 (2001).

27) Hayashi H., Suzuki Y., J. Physiol., 511, 573-586 (1998).

28) Grossmann K. F., Brown J. C., Moses R. E., Mut. Res., 434, 29-39 (1999).

29) Fu Y., Hsieh T., Guo J., Kunichi J., Lee M. Y. W. T., Darzynkiewicz Z., Woo J. M., Biochem. Biophys. Res. Commun., 322, 263-270 (2004).

30) Sudbery P., Gow N., Berman J., Trends Microbiol., 12, 317-324 (2004).

31) Houssin C., Nguyen D. Y., Leblon G., Bayan N., FEMS Microbiol. Lett., 217, 71-79 (2002).

32) Sandvig K., Losnes S., J. Biol. Chem., 257, 7504-7513 (1982).

33) Uddin O., Malik A., Azam S., Hadi N., Azmis A. S., Parveen N., Khan N. U., Hadi S. M., Toxicol. In Vitro, 18, 435-440 (2004).

34) Spedding G., Ratty A., Middleton E., Jr., Antiviral Res., 12, 99-110 (1989). 